\title{
The Political Economy of News Reporting and Poverty in Nigeria
}

\author{
Joshua Suleiman, \\ Department of Mass Communication, \\ Babcock University, Ilishan-Remo, Ogun State, Nigeria \\ Dr. Olusegun Ojomo, \\ Department of Mass Communication, \\ Babcock University, Ogun State, Nigeria
}

Doi:10.19044/esj.2019.v15n22p213 URL:http://dx.doi.org/10.19044/esj.2019.v15n22p213

\begin{abstract}
This paper examines the political and economic factors that underpin Nigeria's media. It seeks to understand whether these factors influence media content and invariably, poverty level in the country. Nigeria's economy has depreciated over the past few decades. Unemployment stands at 23 per cent, with more than half a million of the citizens living on less than $\$ 1.90$ a day, more than any other country on earth (Knoema, 2011; The Economist, 2019). The paper argues that if the Nigerian media could positively impact the growth of democracy and strengthen democratic institutions as they did in the past, they could also facilitate economic development, and poverty reduction in the country through news reporting. After all, one of the major features of democracy is to seek the happiness of the majority of the citizens by adequately providing for their wellbeing. It is therefore important to assess how the Nigerian media can provide useful information that can ensure poverty reduction. This paper draws on review of past studies, journal articles, newspaper and online publications in the related area. The paper recommends that the National Broadcasting Commission should mandate broadcast organizations to devote 80 percent of their broadcast to development information, events and conditions about the people of the state where they operate.
\end{abstract}

Keywords: Political economy, News reporting, Poverty reduction, Rural areas, Communication policy

\section{Introduction}

Nigeria is one of the most endowed countries with natural resources, and human population in Africa. The country has over 200 million people. 
Over the years the quality of life of the people has raised serious concerns among local and international organizations. No fewer than 94 million Nigerians live on less than $\$ 1.90$ a day, the lowest in any country (The Economist, 2019). Lack of infrastructure and basic social amenities, high unemployment at 25 per cent, low accessibility to healthcare services, polluted environment, inadequate housing, food insecurity, and shrinking access to education due to high cost are common features of the country. This largely accounts for the high poverty indices in the country (Olayiwola, 2014). The situation is worse in the rural areas. The Economist (2019) reported that by 2030, a quarter of the world's very poor people would be Nigerians. This frightening prognosis implies that Nigeria's prosperity hinges on pragmatic efforts by the government in harnessing the potentials of its people. This study assesses the performance of Nigeria's contemporary media as it affects the economic prosperity of the citizens. To address this issue, the paper looks at past efforts by government to tackle poverty in Nigeria, the constitutional role of the media, effects that a capitalist ownership base has on news content, the challenges faced by the Nigeria media industry, and the critical role that Nigeria's contemporary media should perform.

\section{Poverty and Past Efforts at Addressing It in Nigeria}

The worry about poverty and income distribution among nations dates back to the 1970s. At the time, the United Nation's Committee for Development Planning declared that the efforts needed to tackle this concern require engaging in necessary 'war on poverty' (UN, 1970). The World Bank (1990) joined the UN in the efforts to fight poverty by focusing on economic growth that generates employment and income for the poor; development of human resources (education, health, and nutrition) which provides the poor with a means to exploit the opportunities created by economic growth; and establishment of a social safety network / initiative for the poor who are unable to benefit from growth and human development opportunities owing to physical and mental disabilities, natural disasters, civil conflict, and physical isolation.

Nigeria has pushed a cause for poverty eradication since independence. As a result, poverty alleviation programs more or less have become a feature of every government. Currently, poverty alleviation programs are designed to realize the Millennium Development Goals (MDGs) alongside every member state of the United Nations (OSSAP-MDGs, 2013). In 2014 Nigeria ranked third among nations whose majority live in extreme poverty (United Nations, 2014). In 2018 it ranked as the Country with the highest population of poor citizens. The Guardian reported that a former Senior Special Assistant to the President on Millennium Development Goals (MDGs), Dr. Precious Kalamba Gbenoel admitted that eradicating poverty has remained a major challenge 
confronting the country in the achievement of MDGs (Okeke, 2014). Scholars have attested to the importance of the media in development. Anaeto and SoloAnaeto (2010) argue that the development media theory, stipulates that media should support and promote national development programs until a nation is well established and its development is very much on course.

Poverty refers to a condition of destitution and indigence. It means to be needy, impoverished, deficient, lacking, worthless, miserable, pitiable, unfortunate, and wretched (Collins Gem Dictionary and Thesaurus, 1992). In the view of World Bank (1970), poverty is the inability of certain persons to reach a minimum standard of living. This correlates with the view of Aluko (1975) that sees poverty as absence of basic necessities of life. These basic necessities include enough food to eat, a low rate of infant mortality, high life expectancy, high educational opportunities, quality water, job opportunities, adequate health care and good housing. A broader definition of poverty regards it as state of being deprived of the information needed to participate in the wider society, at the local, national or global level (ZEF, 2002).

Although successive governments initiated poverty reduction programs in the Country, they failed to achieve their objectives. Some of the anti-poverty programs that have been introduced by successive governments to improve the standard of living of the people include: Accelerated Poverty Alleviation Program, Peoples Bank of Nigeria, 1987, Community Bank, 1990, Better Life Program for Rural Women, 1987, Integrated Community Development Project, and Local Economic Empowerment and Development Strategy, (Paul, Agba \& Chukwurah, 2014; Onah, 2006a; Abdulhamid, 2008). Others were the National Poverty Eradication Program, 2001, Rural Electrification Scheme, 2006, Directorate of Foods Roads and Rural Infrastructure, 1987, National Directorate of Employment, 1986, and Primary Health Scheme. Even with those programs, the condition of millions of Nigerians particularly those in the rural areas, has progressively deteriorated.

\section{Constitutional Role of the Nigerian Media}

Studies have, however, shown that the media is an important instrument of growth and development. This is anchored on the premise that information is power, particularly so at this time when it has become very clear that there is an inextricable correlation between the level of poverty experienced by a people and the level of information available to them (Danbatta, 2016). The role of the media in national development include serving as sources for valuable information on development such as providing guidance and advice to farmers via radio and TV on the use of seeds and fertilizers in support of agricultural extension workers. The agricultural extension workers first helped to promote the concept of development communications. The media also serve as means of expression for the 
marginalized, the dispossessed, the persecuted, and they are the public's de facto ombudsman regarding people's complaints, grievances, and beliefs (Jabar, 2013). To this extent, a society stands the chance of working normally and realistically with the inclusion of the media as key variables in the scheme of development (Merrill, 1971). Studies have also found a high correlation between the measures of economic growth and measures of communications. Lasswell (1948) and Lerner found a correlation between urbanization, literacy, media participation, and political participation.

Ninety per cent of the over 200 million Nigerian population live in the rural areas. They lack the opportunity to be informed, and heard by government. Moreover, their elected representatives are far from them, and do nothing to meet the development needs in their communities. They do not have access to media platforms to express their plights, and convey their views on the type, scope, and shape of the development programs that the government could implement to meet their needs and to reduce their poverty level (Dukeshire \& Thurlow 2002). The media's capacity as agents of development is well documented by scholars (e.g. Akashraj \& Pushpa, 2014; Inuwa, 2007; $\&$ Lasswell 1948). Development is achievable if the media focuses more on reporting the plight of the people and their communities. In doing so the media can bring government up to speed with the critical challenges that the citizens face, and thus force them to direct the needed resources to address these challenges in order to improve the living conditions of the people.

Section 24 of the 1960 Constitution of the federal republic of Nigeria empowers the media to monitor governance and the welfare of the citizenry. Whereas sections 25, 36 and 39 of Nigeria's 1963 Constitution empower the media to complement the executive, legislature and judiciary in the cause of nation building (Daramola, 2006), both constitutions charge the mass media to oversee the conduct of affairs by the three arms of government. Similarly, sections 36 and 39 of the 1979 Constitution institutionalize and codify the surveillance role of the mass media in order to stimulate national development. In addition, section 22 of the 1999 Constitution empowers the media to function as the watchdog of the society. This aims at compelling the government to be responsible and accountable to the people. These responsibilities are assigned to the Nigerian media to stimulate the economic and political growth of the nation and the prosperity of the citizenry. The question, however, is, to what extent have the Nigerian media through their content - news, editorials and features - performed these functions to reduce poverty in the country?

Oseni (1999) notes that the media is the conscience of the nation whether under a totalitarian or military or democratic regime, and that the primary aim of the media is to inform the people and hold the government accountable to the governed. Affirming this position, Pulitzer cited in Oseni 
(1999) asserts that the major role of the mass media is to oversee the safety and welfare of the people who trust them. Similarly, Abati (1999) opines that whether a media organization is patriotic or cynical, it is a question of responsibility. This implies that the media, in any society, ought to exercise responsibility somehow. It also presupposes that the media has the capacity to impact on society positively through education, mobilization and persuasion ((Okunna, 2000) as cited in Owolabi \& O'neill, 2014; \& Raufu, 2011). There will be stagnation of national development if there is no media to ensure constant flow of vital information for economic growth. They are effective means of communication in Africa (Jallov, 2012) and can be used to propagate government programs on poverty alleviation, leading to better understanding and participation in development by the masses. The media, through the agenda setting power and roles that border on development of the society, influence the importance that audiences place on issues (Owolabi, 2014).

\section{Theoretical Framework}

This study is underpinned by three theories. Theoretically, the development media theory confers on the media the task of promoting development, amid grassroots participation by producing contents that would meet cultural and social needs. Anaeto and Solo-Anaeto (2010) assert that development media theory points out that the media must continue to support and promote national development programs. This function of the media relates to the media social responsibility theory which explains that the media has an obligation to be responsible to the public and if it is not so, then some agencies of the public should enforce it (Raufu, 2011; Hutchins' Commission, 1947). The theory of social responsibility demands the press to inform and uphold the truth, and present the views of the citizens. Public opinion and professional ethics are expected to serve as regulators of the activities of the media. For instance, the constitution of the Federal Republic of Nigeria grants the press powers as the fourth estate of the realm to perform its role freely, to inform, educate and enlighten, hold government accountable to the people, and facilitate the nation's development. This role is also contained in the Nigerian National Communication Policy of 1990 and the reviewed edition of 2010.

The policies recognize the power of the media to facilitate exchange of information among the citizens at all levels, promote economic growth and national development. The deregulation of the Nigerian media space provides the fertile ground to realize this objective. The Nigerian government deregulated the media sector to achieve plurality of ideas and access to information and information resources by all Nigerians. This is to enable the citizens get informed about development information and projects, and participate in the development process and activities of government. However, 
the capitalist ownership structure of the media and the media's proclivity towards the corporate and political elite tend to act as obstacles to the media's performance of their social responsibility function. Some of the objectives of the Nigerian National Communication Policy (NNCP, 2010) are to:

- Positively affect the quality of life of the peoples of Nigeria;

- Facilitate coordination and systematic enhancement of national communication strategies and activities to support development;

- Promote participation in national dialogue on development issues by all citizens, consistent with the emerging democratic culture and national constitutional provisions;

- Foster access to information and communication infrastructure and new technologies for all citizens; and

- Promote interchange of balanced information at community, national regional and international level.

The two editions of the National Communication Policy accept the mass media as institutional vehicles for the achievement of the objective of enhancing the quality of life of Nigerians. They are therefore to report every aspect of the Nigerian society, and every part of the Country so as to bring about the desired development. This is possible only by exercising editorial independence - pledging loyalty to professionalism rather than ownership or commercial interest. The media may achieve this objective by ensuring that news reports contain information for and about the people on development. The gatekeeping theory is applicable to this function as it refers directly to gate keeping processes in the newsrooms. It creates a link between the choice of information that the media give or do not give to the public and the powers conferred on the gatekeepers, e.g. reporters, editors, and media owners. This theory states that editorial gatekeepers choose what news to use and how to use them. It states that this selection procedure results in the reflection of the gatekeepers' ideologies and organizational beliefs (McGregor, 1997). For example, in Nigeria, many factors such as social and political biases and economic demands of media owners, advertisers, audiences and gatekeepers' views determine the selection of news reports.

Government, business players or political individuals who are agents of government own most media organizations in Nigeria. This ownership influences the content of media product such as news. Media owners act as gatekeepers of reports before they are published or broadcast by their media organizations. Aware of the negative consequences that this portends for news reporting, the Nigerian Guild of Editors in 2018 urged publishers and broadcast media owners to allow for objectivity in news reporting and professionalism in journalism. 


\section{Nigeria's Poverty and Poverty Reporting in History}

Nigeria ranked 152 of the 188 member nations in the United Nations Development Program 2016 Report on Human Development Index. The Daily Post's (2018) report affirmed the UNDP's position when it stated that Nigeria had overtaken India in world's extreme poverty ranking with 87 million of her citizens living in extreme poverty compared to India's 73 million people. A BBC report quoted Nigeria's National Bureau of Statistics (NBS) as saying that in 2010,60.9\% of the nation's citizens were living in absolute poverty despite growth in the economy. The figure was an increase over the 2004 figure of $54.7 \%$. The report predicted a further rise in the nation's poverty level in the years ahead. The Economist (2019) affirms this prediction, noting that Nigeria's economy will continue to fall for at least the next six years.

The above statistics also affirm the position of Toyin, Timothy, and Funsho (2015) that $90 \%$ of Nigerians are poor and they live in rural areas, while $58 \%$ of Nigerians who are poor live in urban areas. They assert that though Nigeria's economic growth was increasing, it was not decreasing the level of poverty, or the severity of the impact of poverty on the people. This support the NBS 2010 report that poverty will increase as the years roll by. A 2016 report in the Vanguard states that, of the 112 million poor people in Nigeria who live below the poverty line, majority are in the rural areas and they practice agriculture. A similar report by Knoema paints a negative picture of the plight of the rural people; stating that the rural poverty rate in Nigeria was $56.6 \%$ in 2003 .

The rural areas lack infrastructures such as schools, roads, electricity, and communication systems such as newspapers, radios, televisions and Internet to keep abreast of developments around them and elsewhere in the world. The crucial challenge remains how to develop the area both in terms of economic and human resources, as well as infrastructure. Human and economic resources can be developed with increase in the quantity and accessibility of information to the rural areas as well as increase of information about the poor conditions of living of their people.

Orji (2005) informs that provision was made for the media coverage of every poverty alleviation program since the program first began in the 1970s. Unfortunately the media failed in their responsibility to ensure that the citizens were well enlightened about it. For example, whereas there was no deep rooted conceptualization of the Better Life Program to address the real problems, while the activities of the initiators and implementers of the programs were reduced to slogans and jamborees by women of military officers and their influential civilian counterparts in the corridors of power (Orji, 2005), the media did little to report and analyze these weaknesses. The Family Support Program on the other hand sponsored media headlines, news talk, and television and radio discussions to create awareness for the program. 
But there was nothing tangible to show how these programs impacted the lives of the poor masses for which the programs were meant.

Aderogba (2012) shows that a huge number of people claimed that they were not aware of the federal government poverty alleviation programs of NAPEP, NDE, and NEEDS in their area in Iwo, Oyo State. Those who said they were aware of the programs had very limited knowledge of what the programs entailed. However, as at 1986, the awareness of poverty alleviation programs was higher. In 2000, the awareness level dropped. It further dropped in 2001 despite the fact that there has been increase in the number of media organizations, online publications, and social media (Owolabi \& O'neill, 2013).

The poor attention of the media to poverty issues and conditions of the rural population contributes to the nature of Nigeria's slow development and also accounts for the increasing poverty and unemployment in the country (Osakwe, 2010). This suggests that the media have been doing little to put serious efforts at bringing the attention of government to the failing methods of development that it has adopted in its attempt to achieve growth of the productive capacities and structural transformation necessary for generating employment opportunities and reducing poverty. Thus, unemployment and inequality continue to be on the rise and so does poverty. While Ibietan and Ekhosuehi (2013) note that lack of coordination and harmonization of programs and policies both within the tenure of an administration and those succeeding it have been the impediment to development in Nigeria, Raheem and Bako (2014) say one of the reasons for the failure of the various development programs has been the lack of people's participation in those programs. Makinde (2005) agrees with this position, maintaining that the target population is usually not given the opportunity to contribute in the formulation and implementation of policies that concern their wellbeing. The media through news reporting could offer this opportunity of participation but they showed no interest in poverty matters. This could contribute to the high level of poverty in the country, particularly in the rural areas.

Ogwezzy (2014) in a report in The Nation of January 29, expressed worry about poverty and its negative effects, especially in the rural areas, which could remain endemic unless there was a change of attitude by the media. The author states that the reporting of poverty issues in The Nation, The Guardian, The Punch, Daily Sun, Vanguard, and Thisday was generally low on rural areas. Out of a total of 627 reports across the newspapers monitored in April 2013, reports with scope on rural areas were 143, representing 23 per cent of all reports on poverty issues, while reports with scope on urban areas was 315 representing 50.2 percent. This shows that the media are not showing enough concern for rural development and poverty reduction. 
The content categories of poverty studied by Ogwezzy (2014) includes issues such as lack of adequate access to credit; lack of education, low education, illiteracy; unstable employment, unemployment; isolation, marginalization, and social exclusion; food: hunger, and famine; inadequate health care, lack of access to care, and disease; dangerous living conditions, and homelessness; poor infrastructure such as roads, telecommunications, etc.; lack of land tenure, and ownership; mental health issues such as depression; poor sanitation; inadequate access to clean water and poverty in general. The implication of this study is that, poverty reporting does not seem an important subject for the media because poverty is the social syndrome of the poor who lack basic purchasing power, and cannot guarantee the continued existence of the media. On the other hand, corporate organizations in Nigeria are interested in their businesses and how much profit they can make. The media provide them the platform to achieve this. This relationship encourages the promotion of the interests of corporate organizations - the elite class - above the interest of the poor masses. Zotto (2015) states that government predominantly controls the broadcasting media in Nigeria. These government-controlled media are the only ones with national coverage. Zotto asserts that because investors in the private-owned media have vested interests in national politics, or close ties with political leaders, and because the advertising market is made up of a high buyers' concentration, they limit media professionalism.

The news content of AIT, NTA and TVC are indicative of Zotto's (2015) view. Their news content is mainly on corporate executives, their businesses, and the politico-economic and political landscape, and their influence on government's policies; while inadequate reporting is recorded on poverty issues. This accounts for increasing poverty in Nigeria, despite the declining rate of poverty in Sub-Saharan Africa (Maku, Ogwumike, \& Adesoye 2014). The factors attributed to this lack of media interest in poverty issues are partly commercial and editorial interest, and ownership structure. Wood and Barnes, (2007) state that poverty is such an everyday reality and so widespread that it is not considered of interest to public audiences and, therefore, the media find it not sellable. These commercial and political interests of media owners are the politico-economic influences on the media.

\section{Influence of Politico-economic Actors on Nigerian Media}

Akinfeleye (2016) blames Nigeria's underdevelopment and increasing poverty on the failure of the media to capitalize on their inherent power to facilitate rural development and to improve the poor conditions of Nigerian citizens. Iredia (2016) shares Akinfeleye's (2016) view, stating that the Nigerian media have become too elitist to bother about the poor people and the rural areas. The elitist nature of the Nigerian media may have arisen from the control of the means of production by the privileged few political and 
economic elite who wield huge influence on media content due to their massive financial capacity to buy media space. Yet, the responsibility of the Nigerian media is not to the businessman or the politician but to the good governance of the nation where all will live happily enjoying the basic necessities of life (Ekpu, 2018). Although Murdock (1990), Herman and Chomsky (1988), McChesney (1999), and Miller (1996) are unanimous that constant reporting of the views and activities of the political and corporate elite is largely influenced by their economic advantage; however, by focusing their reporting on political and economic actors of influence and affluence, the Nigerian media are prioritizing economic interest over their social responsibility of galvanizing the citizenry for development, and equipping them with necessary information to better their lives. The media's preference for reports on the political and economic is termed as commercialization of media content. The consequence of commercializing media reports is that only those with the financial resource will always have access to the use of the media for their views and activities alone to be sold to both government and the general public. While this practice would boost the elite's political power, promote their economic hegemony, it shifts attention away from reporting the ordinary people and their pressing needs. Media sociologist Sigal (1973) views economic considerations as constraints on news work and weaken the insulation of the news department from extraneous factors that act against professionalism (Veronis, 1989). Good journalism serves the public good and a commitment to its ultimate wealth (Ekpu, 2018).

Commercialization and media ownership are two of the key elements addressed in Esser and Pfetsch (2004), Holtz-Bacha (2004), and McChesney (1999). As Hallin and Mancini (2004) opine, the media have become less differentiated from economic systems with the emergence of commercialization (Yuksel 2013). Thus Ogbodo (2018) views the overbearing influence of Nigerian media owners on editors as a minus for professionalismdriven media content. This affirms Curran (2000), Chomsky (2003), and Ogenga (2010) who assert that the operational behavior of the media is colored and affected by their owners, and the financial support from the capitalists. Under such circumstances the media will only produce content that will sustain the capitalist system (Hesmondhalgh, 200) Mosco, 1996; Ogenga, 2010; William, 2003). The economic and political interests of media owners allow the media to surrender their control of content to corporate organizations and institutions of state by solely depending on them for their revenue. This attempt to meet the needs of corporate organizations and institutions of state subjugates the needs of majority of Nigerians who live in poverty, and whose conditions are rarely reported by the media. In this way the Nigerian media may be seen as part of what Wasco (2005) terms a wider corporate order that is both exploitative and undemocratic. Omojola (2010) states that as long as 
the Nigerian media continue to place commercial interest above public interest, particularly on reporting the deplorable conditions of the people, most of who live in rural communities

\section{Nigeria's Media's Capability to Transform Lives of the Rural Poor}

Preceding discussions have demonstrated that the public media is capable of reducing poverty and bringing about positive life-changing experiences to Nigeria's poor population, but they have failed to do so because of their focus on commercial news rather than the issues of poverty that they consider not to have commercial value for them. Thus, there is paucity of programs on radio and television that bring development information to empower the poor population and transform their lives. The Northern Nigeria under the provincial and native authority administration, used film to improve agricultural production, especially after the collapse of the textile industries in the United Kingdom due to global cotton drought (Paden, 1986). The Northern Nigeria Film Unit produced films on cotton production, raised awareness and increased cotton yield among local farmers. This earned revenue for the people, improved their living conditions, and contributed to revitalizing the British textile industries. The local people were used as cast, their natural rural environments were used as setting, and their culture and custom were showcased. The Hausa Language was used as a medium of communication. The program galvanized the northern population into cotton production. Cotton was mass-produced to feed both the local and international markets. There was improvement in the people's standard of living as a result of the boom that agriculture enjoyed.

Adamu (2009) emphasizes the role of communication and how television can boost people's participation in the production process. The Ahmadu Bello University (ABU), Zaria's National Agricultural Extension and Research Liaison Services used local languages in radio dramas, interviews, and panel discussion programs. Its impact on their target audience was positive as people's interest in agriculture was rekindled, and it led to increase in agricultural products and income for the local people. The groundnut pyramids in northern Nigeria in the 70s were achievable partly due to the interest in agriculture facilitated by the radio and television programs. This has contributed to the licensing of community radios because of their huge potential to boost the economy and social life of the rural people.

\section{Conclusion}

This paper has argued that the increasing poverty in Nigeria, particularly in its rural areas, is partly due to the inability of the media to actively give expressions to the plights of the rural people, stimulate their capabilities, awareness and participation in development programs. This 
results from the economic and political interests of media owners, as well as commercialization of news content. This scenario threatens diversity of coverage in Nigeria, particularly the reporting of poverty issues despite the increased media freedom in the country. Poverty reporting does not seem sellable and attractive to the Nigerian media, as much as reporting on personality-based elite politics and economy. This paper notes that the structural weakness of the media - ownership influence, is a major challenge for the media in Nigeria. Nonetheless, the media have an obligation to provide an inclusive platform for public debate by involving both the rich and the poor, especially presenting poverty alleviation issues from the viewpoint of the poor, and placing them on the front burner.

\section{Recommendations}

Community broadcasting is part of the strategies in the National Communication Policy to bring development programs closer to the people and provide a channel for them to express their views and opinions and learn new information that can play a key role in rural transformation and local accountability. There is yet no community television. This hinders community's access to information on development programs. Government needs to broaden the rural community's access to the media by dealing with the issue of funding television for the rural communities. This requires making the media cheaper to set up. This will expand access to information, and consequently lead to inclusiveness in development programs. With access to information, people are exposed to new ideas and skills that can make them better able to take control of their environment for their own wellbeing, sieze opportunities that come their way, and ensure self-actualization.

Secondly, the media can set poverty issues as agenda for government. They can also be more deliberate in their coverage of this issue as much as they report on national politics and the economy. Thirdly, most of the contents of both private and public newspaper, television and radio stations are hardly reflective of the multiple needs of the poor people in the states where they operate. This situation should be reversed. In addition, the National Broadcasting Commission should mandate each broadcast organization to devote 80 percent of its broadcast to development challenges and conditions of the people of the state where it operates. The remainder 20 percent may be devoted to national news. The commission can do this by setting compliance parameters and a monitoring group to ensure adherence to those parameters. Currently the National Broadcasting Commission stipulates 70 percent local content and 30 percent foreign content for broadcast programming. This will focus media organizations on reporting more on the local areas. This will facilitate accelerated developments of the rural communities and improve the people's living standards. Also, media practitioners need to ponder the moral 
question of how they wish to be remembered long after they quit the profession: whether they practiced ethically and aided in making lives better for the people in whose interest they pledged to work, or they betrayed the people's interest by sacrificing their need for their own personal interest.

\section{References:}

1. Abati, R. (1999). The media in Nigeria: Patriots or cynics. In T. Oseni (ed.) The media transition and Nigeria. Lagos: Tosen Consult.

2. Abdulhamid, Y. (2008). Nigeria: Vision 2020 and NPC. In Daily Trust Newspaper. 2008. http://allafrica.com/stories/200808050705.html.

3. Adamu, Ladi Sandra. (2009). Use of television for agricultural education by the National Agricultural Extension and Research Liaison Services (NAERLS) of Ahmadu Bello University, Zaria, 1999-2005.In Maiduguri Journal of Arts and Social Sciences (MAJASS), Vol.7, No.1, pp.52-59

4. Aderogba A. (2012). Media preference for an effective dissemination of poverty alleviation Programmes in Nigeria's semi-urban setting: Iwo town in perspective. International Journal of Current Research. 4(03):166-172. Akashraj, D.P. \& Pushpa, C. O. (2014). Role of social media on development. Merit Research Journals vol 2(2) pp015-018. February 2014.

5. Akinfeleye, R. (2016). In Ojo, J. Imperative of a new Nigerian national communication policy. The Punch Newspaper. October, 26.

6. Anaeto S, Solo-Anaeto, M. (2010). Development communication principles and practice. Ibadan: Stirling-Horder Publishers Ltd.

7. Bagdikian, B.H. (2004). The New Media Monopoly, 2nd edn, Boston, MA: Beacon Press.

8. Barnouw, E. and Gitlin, T. (eds) (1998). Conglomerates and the Media, New York: New Press.

9. Basu, A. (2016 ). Understanding Media-Politics-Economy-Society Interrelationship in India: Relevance of Habermas and Chomsky. In a Doctoral thesis titled 'Role of Media in Electoral Politics in India: A Study of General Elections 2014'. Transcience (2016) Vol. 7, Issue 2.

10. Chomsky N (2003) Understanding power: the indispensable Chomsky.

11. Collins and Gem (1992). Dictionary and Thesaurus. Wrotham, London, Glasgow, Great Britain,

12. Constitution of the federal republic of Nigeria (1999).

13. Constitution of the federal republic of Nigeria (1979).

14. Curran J (2000) Rethinking media and democracy'. In: Curran J, Gurevitch Meditors. Mass media and society. London: Arnold 120152. 
15. Curran, J. and J. Seaton (1985) Power without Responsibility, 2nd edn, London: Methuen.

16. Curran, J. and J. Seaton (2009) Power without Responsibility, 7th edn, London: Routledge.

17. Daily Post Newspaper. (2018). Nigeria bi-annual economic update: Fragile recovery. March 5.

18. Donsbach W and Patterson T E (2004) Political News Journalists. Partisanship, Professionalism, and Political Roles in Five Countries. F Esser and B Pfetsch (eds), Comparing Political Communication: Theories, Cases, and Challenges, Cambridge University Press, Cambridge, pp 251-271.

19. Danbatta, U. G. (2016). Institutional mechanism for poverty reduction in Nigeria. A speech delivered at the National Institute for Policy and Strategic Studies, Kuru.

20. Dollar, D., \& Kraay, A. (2002). Growth is good for the poor. Forthcoming: Journal of Economic Growth.

21. Dukeshire, S.,and Thurlow, J. (2002). Rural communities impacting policy challenges and barriers to community participation in policy development. Dalhousie University.

22. Ekpu, R. (2018). At the Nigeria Guild of Editors annual national conference. Asaba, Delta State. October 10-14.

23. Ekwo, U. (1996). "Commercialization of news in the Nigerian media: An impediment to information flow". In: I. E. Nwosu and U. Ekwo (Eds.). Mass media \& marketing communications: Principles, perspectives and practice. Enugu: Thought Communications Publishers.

24. Esser, F. and Pfetsch, B. (2004). Comparing Political Communication: Theories, Cases and Challenges, Cambridge University Media, Cambridge.

25. David, P. (2018). Nigerian economy: Why Lagos works. Financial Times. March 25. https://www.ft.com/content/ff0595e4-26de-11e8b27e-cc62a39d57a0

26. Gandy, O.H. (1997). The political economy of the media Volume 1.UK: Edward Elgar Publishing Limited 87-106.

27. Hallin, D. C. and Mancini, P. (2004) Comparing Media Systems: Three Models of Media and Politics. Cambridge University Media, Cambridge.

28. Haralambos, M, and Holborn, M (2004) Sociology: Themes and Perspectives. London, HarperCollins

29. Herman, E. and Chomsky, N. (1988) Manufacturing Consent: A Political Economy of the Mass Media, New York: Pantheon. 
30. Hesmondhalgh, D. (2007). The cultural industries. (3rd edn.), SAGE publishing

31. Holtz-Bacha C (2004) Political Campaign Communication. Conditional Convergence of Modern Media Elections, F Esser and B Pfetsch (eds), Comparing Political Communication: Theories, Cases, And Challenges, Cambridge University Press, Cambridge, pp 213231.

32. Ibietan, J. \& Ekhosuehi, O. (2013). Trends in Development Planning in Nigeria: 1962 to 2012. Journal of Sustainable Development in Africa, 15 (4): 297-311

33. Ifijeh, V. (2018). Print media: Challenges and prospects. A paper delivered at the Nigeria Guild of Editors annual national conference. Asaba, Delta State. October 10-14.

34. Inuwa, I. M. (2007). Role of media in national development. A paper presented at a workshop on the event of the 27 youth leadership program organized by LEAP Africa, on Tuesday July, 24, 2007 at the British Council, Kano, Nigeria.

35. Iredia, T. In Ojo, J. (2016). Imperative of a new Nigerian national communication policy. The Punch Newspaper. October, 26.

36. Jabbar, J. (2013). Role of Media in National Development in the 21st Century. October 2nd. http://www.criterion-quarterly.com/role-ofmedia-in-national-development-in-the-21st-century/

37. Jallov, B. (2012). Empowerment radio - Voices building the community (Forthcoming). Denmark: Empowerhouse.

38. Jevon, W. S. (1871). The theory of political economy. London: Macmillan.

39. Knoema (2011). Nigeria - Poverty headcount ratio at \$1.9 PPP a day. https://knoema.com/atlas/Nigeria/Poverty-rate. Accessed September 2, 2018.

40. Lasswell, Harold (1948). Bryson, L., Ed. The Structure and Function of Communication in Society. The Communication of Ideas. New York: Institute for Religious and Social Studies, 117.

41. Ma, E.K.-W. (2000). 'Rethinking media studies: the case of China', in J. Curran and M.-J. Park (eds.) De-Westernizing Media Studies, London: Routledge.

42. Makinde, T. (2005). Problems of policy implementation in developing nations: The Nigerian Experience. Journal of Social Science, 11 (1): 63-69.

43. Maku, O. E., Ogwumike, F. O., \&Adesoye, A. B. (2014). Sub-Saharan Africa (SSA) and the millenium development goals (MDGs): Performance and strategic options. 55th Annual Nigerian Economics Society (NES) Conference from 7th-11th November, 2014. Abuja: Nigerian Economics Society (NES). 
44. Margaret, A. B. (1977). The Hutchins Commission, the press, and the responsibility concept. Journalism Monographs, Association for Education in Journalism.

45. McChesney, R. W. (1999) Rich Media, Poor Democracy. Urbana, IL: University of Illinois Press.

46. McQuail, D. (2000). Mass communication theory: An introduction, London, Sage Publication.

47. McQuail, D. (1987). Mass communication theory: An introduction (2nd ed.). Thousand Oaks, CA, US: Sage Publications, Inc

48. McQuail, D., 2010, MacQuails's Mass Communication Theory, Sage Publications, New Delhi.

49. McQuail, Denis (2005). McQuail's Mass Communication Theory. 5th Edition. London: Sage.

50. Merrill, J.C. (1971). The Role of the Mass Media in National Development: an Open Question for Speculation. https://doi.org/10.1177/001654927101700404

51. Miller, M.C. (1996). Free the media. The Nation. www.thenation.com

52. Mosco, V. (1996) The Political Economy of Communication: Rethinking and Renewal, London: Sage Publications.

53. Murdock, G. (1990) "Redrawing the Map of the Communication Industries," in Marjorie Ferguson (ed.), Public Communication: The New Imperatives, Beverly Hills: Sage Publications, pp. 1-15.

54. Nigerian National Communication Policy, 2010. (Reviewed). Federal Ministry of Information, pp. 4,6,9,14-16.

55. Nigerian Mass Communication Policy, 1987. FGP 1345/790/2,000.

56. Ochonogor, I. C. (2008). Mass Media Ethics and the Sustenance of Democracy in Nigeria. In Fred I.A. Omu and Godwin Ehiarekhian Oboh, (Eds.), Mass Media in Nigerian Democracy. Lagos: StirlingHorden Publishers, 116-131.

57. Ogbodo, A. (2018). At the Nigeria Guild of Editors annual national conference. Asaba, Delta State. October 10-14.

58. Ogenga, F (2010). Political economy of the Kenyan media-towards a culture of active citizen journalism. Global Media Journal-African Edition 4: 151-162.

59. Ogwezzy, A. (2014). Nigerian media under report rural poverty. http://thenationonlineng.net/nigerianmedia-under-report-ruralpoverty.

60. Olayiwola, A. (2014). A comparative political analysis of poverty and inequality in Nigeria and Britain. Journal Political Science Public Affairs Vol.2. No.4: 138.

61. Omojola, O. (2010). Mass media interest and corruption in Nigeria. Communication Review, Vol.4, No. 2: 21-39. 
62. Onah, F.O. (2006). Managing public programs and projects. Great AP Express Publishers Ltd., Nsukka, Nigeria.

63. Orji, J. O. (2005). An assessment of impacts of poverty reduction programs in Nigeria as a development strategy, 1970- 2005 (PhD thesis, St. Clement University, TCI). Retrieved from http://stclements.edu/grad/gradorji.pdf.

64. Owolabi, T. O. (2014). Implications of the media coverage of smes for national development in Nigeria. International Journal of Development and Economic Sustainability. 2(3):45-57. Retrieved from http://www.eajournals.org/wpcontent/ uploads/Implications-ofthe-Media-Coverageof- $\quad$ SMEs-for-National-Development-inNigeria.pdf

65. Osakwe, R. N. (2010). Education for People with Special Needs in Nigeria: Challenges and Way Forward. In M. I. Atinmo, J. B. Babalola, O. A. Moronkola and A. I. Atanda. (Eds). Education for Sustainable Development. Faculty of Education, University of Ibadan. 33-43.

66. OSSAP-MDGs Nigeria millennium development goals 2013 Report. OSSAPMDGs, 2013. Retrieved from http://www.ng.undp.org/content/dam/nigeria/docs/MDGs/UNDP_NG _MDGsReport2013.pdf.

67. Owolabi, T. O, O’neill, E. (2014). Mass Media, Governance and Poverty Reduction Strategy in Nigeria: A Role Evaluation. British Journal of Arts and Social Sciences. 17(1):62-74. Retrieved from http://www.bjournal.co.uk/volume/paper/BJASS_17_1/

BJASS_17_01_05.pdf.

68. Oseni, T. (1999). The media transition and Nigeria (ed.) Lagos: Tosen Consult.

69. Oyesanmi O, Eboiyehi F, Adereti A. Evaluation of the concepts, implementation and impact of poverty alleviation programs in Nigeria. Paper presented at International Union for the Scientific Study of Population XXV International Population Conference Tours, France, July 2005, 18-23. Retrieved from http://iussp2005.princeton.edu/sessions/47.

70. Paden, John N. (1986). Ahmadu Bello, Sardauna of Sokoto: Values and leadership in Nigeria. Zaria: Hudahuda Publishing Co.

71. Pan, Z. (2000) 'Improvising reform activities: the changing reality of journalistic practice in China', in C.- C. Lee (ed.) Power, Money and Media, Evanston, IL: Northwestern University Press.

72. Pate. U.A. and Dauda, S. (2013). Media and social economic development in Northern Nigeria. Journal Komunikasi Malaysian Journal of Communication Jilid 29(1): 1-19. https://www.researchgate.net/publication/256106851_media_and_soc 
io economic development in northern Nigeria. [accessed Aug 17 2018].

73. Paul, S. O; Agba, M.S.; Chukwurah, D.C (2014): Rural development programs and rural underdevelopment in Nigeria: A rethink. International Journal of Public Administration and Management Research (IJPAMR), Vol. 2, No 4, December. Website: http://www.rcmss.com. ISSN: 2350-2231 (Online) ISSN: 2346-7215 (Print)

74. Picard, R.G. (1989). Media economics: concepts and issues. Sage publications. 1: 56-70.

75. Raheem,W,M., and Bako, A.I. (2014). ) Sustainable rural development programs in Nigeria: Issues and challenges. Asian Journal of Science and Technology. Vol.5, Issue 9, pp.577-586, September. Available from:

https://www.researchgate.net/publication/295858589_sustainable_rur al_developmet_programmes_in_nigeria_issues_and_challengesn

76. Ramaphosa, C. (1999). The media, the editors and the owners. In Financial Times. 14-05-1999: 20-21.

77. Raufu, G. (2011). Mass media and the society: Issue and perspectives. London: Kagor International.

78. Sigal, L. V. (1973). Reporters and officials. Lexington, MA: D. C. Heath.

79. Smythe, D. W. (1960) "On the Political Economy of Communication," Journalism Quarterly, Autumn: 563-572.

80. The Economist, (2019). Nigerians got poorer in Muhammadu Buhari's first term. https://www.economist.com/middle-east-andafrica/2019/05/29/nigerians-got-poorer-in-muhammadu-buharis-firstterm

81. Toyin, G.A., Timothy, T.A., and Funsho, E.F. (2015). Analyzing poverty situations in rural areas in Nigeria. Journal of Agricultural Science and Engineering. Vol.1, No.4:178-188.

82. United Nation Development Report. (2016). http://hdr.undp.org/sites/all/themes/hdr_theme/countrynotes/NGA.pdf Accessed October 15, 2018.

83. Unite Nations (1970). Ending poverty. https://www.un.org/en/sections/issues-depth/poverty/

84. Vanguard Newspaper. (2016). Poverty: 112 million Nigerians live below poverty line. October 18.

85. Wasco, J. (2005). Studying the political economy of media and information. Comunicacao e Sociedade Vol. 7: 25-48.

86. White, D. M. (1950). "The "gate keeper": A case study in the selection of news". Journalism Quarterly 27: 383-391. 
87. Williams K (2003) Understanding media theory. Bloomsbury Academic.

88. World Bank, (1990). World development report: 1990. http://documents.worldbank.org/curated/en/424631468163162670/W orld-development-report-1990-poverty

89. Wright, C (1959) Mass Communication: A Sociological Perspective. New York, Random House

90. Yüksel, Y. (2013). An analysis of the media and government relationship. Selçuk Iletişim. Vol. 8. 